\title{
THE ROLE OF ECCENTRIC REGIME OF LEG MUSCLE WORK IN ALPINE SKIING
}

\author{
Robert Ropret \\ University of Belgrade, Faculty of Sport and Physical Education, Serbia
}

\begin{abstract}
Alpine skiing is characterized by a great number of leg movements with muscle contractions in eccentric regime. The role of these movements is to absorb gravitation and inertial forces, manage skis more precisely and maintain balance. Recent studies have determined the volume, duration and intenisty of eccentric contractions as well as the basic characteristics of movement amplitudes and velocities. Based on the previous findings the experiments involving eccentric training using a bicycle ergometer confirmed a positive impact that this kind of training has on increasing maximum power, strength, endurance, coordination, injury prevention, metabolic work efficiency, more efficient work with longer muscle length and its role in miming skiers' movements. This paper is an rewiev of the studies so far in the field of kinematics, skiing dynamics and the effect of eccentric training on the development of athletes' performances.
\end{abstract}

Key words: TRAINING / POWER / ECCENTRIC CONTRACTION / EXERCISE

\section{INTRODUCTION}

Alpine skiing, either recreational or competitive, implies movements on skis down a slope, under the gravitation force, where a skier performs movements in order to change direction and control speed. The movements are performed under conditions of concentric (CON), isometric (ISO) and eccentric (ECC) muscle contractions. Due to gravitation and inertion a great number of movements are performed under conditions of ECC regime of leg extensor muscle work (Berg \& Eiken, 1999). The ability to control the power of knee extensor muscles in ECC regime may be a key limiting factor of the proper and successful skiing technique manifestation. The findings regarding the characteristics of ECC training regime, dynamic and kinetic characteristics of alpine skiing, may contribute to training session planning and improving competitors' performances. The aim of this paper was to determine the adequate methods and means for enhancing the skiers' leg strength, based on the findings about the importance of the eccentric regime of extensor muscle work during skiing. The research included a rewiev of PubMed, Medline and Google search engine bases of papers. The papers were selected by combining the key words: alpine skiing, strength training, and eccentric contraction. The overview included the papers relevant for the topic published in the period between 1955 and July 2016.

\section{CHARACTERISTICS OF ECCENTRIC MUSCLE WORK REGIME}

Eccentric contraction implies muscle work in the conditions where external load exceeds muscle power, which causes the lengthening of muscle-tendon system and muscles work in the so-called „eccentric regime-ECC" (Lindstedt, Reich, Keim, \& LaStayo, 2002). ECC contraction is important for decelerate, brake or absorbing energy reducing, interrupting or absorbing the energy of movement. The absorbed energy may be dissipated as heat or as elastic energy. In the first case, when the movements are slower, the effect of muscle work is load absorption such as in skiing, running downhill or during landing movements. 
In the second case, during fast and cyclic movements (sprints, jumps), the absorbed energy is dissipated and enables a more efficient "stretch-schortening cycle" (SSC). The reasons for such effects of ECC contraction have not been fully explained. Some authors believe that the absorbed energy at the end of ECC contraction is released as elastic energy in tendons, during a fast movement which follows (in a srpinglike manner). In order to make use of a reverse effect, the time between the end of ECC and the beginning of CON contraction ("coupling time") needs to be short since otherwise elastic energy would be transformed into heat. Originally, it was believed that the time cannot be longer than $0.15 \mathrm{~ms}$, and then Wilson, Elliot and Wood (1990) concluded that the effects of lower intensity may be used within the period of 4 seconds. Other authors believe that the enhanced effect of CON contraction is a result of the effect reflex has on stretching. Others still believe that ECC contraction allows muscles to establish their (pre)activation at a higher level and start CON contraction with a greater activation capacity (Linthorne, 2001).

\section{Eccentric training and adaption processes}

Compared with the movements in CON regime, the muscle work in ECC regime is more efficient in terms of energy and metabolism, even up to $50 \%$ (Isner-Horobeti, Dufour, Vautravers, Geny, Coudeyre, \& Richard, 2013). Thus, in ECC training there is a possibility to load muscles significantly more and with lower metabolic requirements - "more efficiency with less effort" (LaStayo, Pierotti, Pifer, Hoppeler, \& Lindstedt, 2000). During ECC ergometer cycling the consumption of $\mathrm{O}_{2}$ may amount to $1 / 6-1 / 7$ of the consumption in relation to the cycling in CON regime (Biglan-Ritchie \& Woods, 1976). Vorgt (2011) achieved the total volume of work of 240 tons per training session in his experiment with ECC cycling on a bicycle ergometer, which is almost impossible to achieve by the cycling in CON regime. La Stayo et al. (2000) in their experiment involving cycling on a bicycle ergometer, with the work intensity of $65 \% \mathrm{VO}_{2}$ max, recorded the work with the loads four times greater in ECC regime ( $489 \mathrm{~W}$ ) compared to a group working in CON regime (128 W).

Adaptation processes under the influence of ECC training reflect in the changes in nervous and muscle system. Muscle mass is increased due to the hypertrophy of fast-twitch muscle fibres of type Ia and IIx (Folland \& Williams, 2007; Friedmann-Bette et all,
2010; Guilhem, Cornu, \& Guevel, 2010; Baroni, Rodrigues, Franke, Geremia, Rassier, \& Vaz, 2013). The adaptation changes upon ECC training result in an increase in contraction velocity and muscle spindle length as well as an increase in the capacity to use the accumulated elastic energy in muscle-tendon system (Lindstedt, et al., 2002) more efficiently, an increase in overall work efficiency and improved injury prevention.

Fatigue is an important factor of the manifestation of elastic muscle features, since it reduces the effect of muscle activity. By applying different training models it has be found that muscles need more than 24 hours to recover after hard ECC training and, due to a high volume of work, it is possible to apply the maximum of 2 or 3 ECC training sessions per week (LaStayo, 2000; Vogt \& Hoppeler, 2009).

\section{The effect of eccentric training on strength development}

The advantages of ECC training in relation to CON training method have been proven in several experiments in untrained subjects. Several experiments lasting 7-10 weeks have shown a positive effect on increasing maximum isometric power of $36 \%$ (LaStayo et al., 2000) and strength in sets of high jumps by $7 \%$ (Elmer, Hahn, McAllister, Leong, \& Martin, 2012) as well as that the method of "high volume-low intensity" exercises in ECC regime has shown better results compared to the "high intensity-low volume" method. In two experiments of similar duration (number of trainings $\mathrm{x}$ number of sets $\mathrm{x}$ number of repetitions), (Guilhem, et all., 2010; Guilhem, Cornu, Maffiuletti, \& Guevel 2013) applied two methods in ECC regime exercises: isotonic and isokinetic. Finally, it has been determined that the participants in the isokinetic experiment performed twice the volume of work on average, yet a greater effect on strength increase was achieved by the isotonic method (2.4\%).

A few studies, in trained athletes, also indicated a positive effect of ECC training. Various experiments where two groups applied CON and ECC training regime lasted 3-10 weeks, 3-4 training sessions per week. Despite different methodology of the experiments, the groups with ECC regime showed better results than the groups with traditional CON training regarding the enhancement of: jumping height (8\%), movement frequency by $11 \%$ (Lindstedt, et al., 2002), maximum isometric hamstring muscle power by $11 \%$, torque at the velocity of $60^{\circ}$ s by $0.4 \%$ per 
session (Mjolsnes, Arnason, Osthagen, Raastad, \& Bahrl, 2004); jumping height by $11 \%$ (Sheppard, et al., 2008); percent of IIa fibre type; strength and jumping height by $5 \%$ (Cook, Beaven, \& Kilduff, 2013).

\section{The effect of eccentric training on coordination}

$\mathrm{CON}$ and ECC muscle contractions differ in the process of movement programming at the level of the central nervous system (CNS). The study by Guilhem et al. (2010) has shown a higher level of EEG activity of the cortex with ECC contraction in relation to CON contraction. At muscular level, with similar power intensity a lower level of EMG activity was recorded during ECC compared to CON contraction (Biglan-Ritchie \& Woods, 1976). The authors suppose that a smaller number of motor units are activated during ECC contraction in relation to the CON contraction of the same intensity. This results in an increase in mechanical load per an activated motor unit. Therefore it is harder to control and coordinate movements during ECC contraction.

\section{Eccentric training modalities}

According to the studies so far there are two models of ECC regime training that are frequently applied (Roig, et all., 2009; Vogt \& Hoppeler, 2009; Guilhem, et all., 2010; Elmer, et all., 2012; Isner, et all., 2013; Elmer \& Martin, 2013):

1. „High intensity - low volume“ approach is a training with heavy loads (around 1 repetition maximum (RM), and a small number of sets, mainly performed in a "pure eccentric“ or "mixed eccentric and concentric contraction" manner, with "isotonic“ or ,isokinetic“ exercises. It is generally performed using ergometers with additional load.

2. "Low intensity - high volume" approach is a training characterized by a greater number of repetitions and submaximal load. It is most frequently performed with ECC ergometers.

ECC training with supramaximal and maximal load ( $\geq 1 \mathrm{RM}$ ) increases maximum power and muscle mass. By submaximal loads ( $\leq 1 \mathrm{RM})$, the enhancement of power and muscle tone is achieved. In order to develop these performances the training includes exercises with overload ( $\geq 1 \mathrm{RM}$ ), plyometric exercises, exercises using one's own body (e.g. „Nordic hamstring exercises") or exercises using ergometers (inertial load ergometers and bicycle ergometers).

\section{CHARACTERISTICS OF LEG MUSCLE ACTIVITY IN SKIERS}

Contrary to the belief that alpine skiing represents a dynamic activity with lots of explosive movements, the angular velocities in knee and hip joints show that skiing is a sport which is not characterized by maximum movement velocity (Berg, Eiken, \& Tesch, 1995; Patterson, Raschner, \& Platzer, 2009). Average angular velocities in the knee joint range between $20-40 \%$ and the maximum recorded velocities of $69 \%$ are far from the angular velocities in the knee joint of sprinters and jumpers $\left(1000^{\circ} / \mathrm{s}\right)$ or cyclists (200-400\%) (Berg \& Eiken 1999. The speed of power generation is lower and maximum values are reached later on and what makes skiing different from the majority of other sports is that a greater part of a turn is dominated by ECC contractions, due to the movement down a slope. Body moving continuously down a slope with an increased velocity $(30-100 \mathrm{~km} / \mathrm{h})$ generates kinetic energy and thus a heavy load to the knee joint extensors. The loads that skiers endure during a turn are 2-4.5 G (Hoppeler, 2014), i.e. $58-112 \%$ of maximum voluntary isometric contraction (MVC). The duration of ECC contraction phase is $84.5 \%$ in slalom (SL) and $88.2 \%$ in giant slalom (GSL) out of the total turn duration, which indicates a large volume of ECC regime of muscle work in order to manage inertial forces and maintain position (Berg, Eiken, \& Tesch, 1995).

Regarding the role of certain fibre types, the research by Vogt \& Hoppeler (2012) indicated a small but significant dominance of slow-twitch (I) in relation to fast-twitch fibres (II) in the sample of elite skiers as well as correlation between successfulness in competition results (FIS competition points) and slow-twitch fibre type (I). It is assumed that the velocity and intensity of the entire ECC and CON contraction cycle depends on the type of muscle fibres and their length.

Movement amplitudes, knee joint angles, duration, velocity and frequency of movements as well as the characteristics of muscle activity indicate that the movements in skiing may be classified between slow SSC and shock absorbing function. The specified characteristics represent a challenge for planning and implementation of ECC exercises in strength training of alpine skiers. 


\section{THE EFFECT OF ECCENTRIC REGIME EXERCISES ON SKIERS' PERFORMANCES}

In accordance with the previous findings, some studies on the effect of ECC training on skiers' power, endurance and coordination enhancement have been conducted. Vogt (2011) applied a 6-wk training using an eccentric cycle ergometer in his experiment with skiers. The control group performed a traditional CON training 3 times a week lasting 60 min, while the experiment group had $40 \mathrm{CON}+20$ ECC minutes of training with cycle ergometer. Both groups recorded an increase of $10 \%$ in ISO power, whereas only the experiment group recorded an increase of $7.9 \%$ in a high jumping test. Gross, Luthy, Kroell, Muller, Hoppeler and Vogt (2010) and Vogt \& Hoppeler (2012) carried out the 5-week experiments with elite skiers. In addition to a traditional strength training (without jumping), the skiers also applied a set of 20 minutes on ECC cycle ergometer 1-2 times a week. The load was gradually increased and finally it was $140 \%$ of the initial load (from 404 to $965 \mathrm{~W}$ ). An increase was recorded in isometric power (12\%), leg muscle mass (1.9\%), maximum strength in high jumps (8.8\%), squat jumps (92\%) and power in ECC contraction as well (100\% BM). Despite the intense but gradual load increase, the occurrence of "muscles soreness" was not recorded. The above mentioned studies indicate that the implementation of ECC training affects the enhancement of maximum strength and power, without jumps. The research by Vogt, Dapp, Blatter, Weisskopf, Suter and Hoppeler (2003), using an ECC ergometer showed that more successful skiers have better coordination of movements (the relation between load and demonstrated strength). The correlation between these results was recorded in the skiers in SL and GSL but not in DH (downhill). This result is understandable when we take into account the movement dynamics (longer and slower movements in $\mathrm{DH}$ ) and the protocol of the test used (higher movement frequency). The results of ECC training indicate that good coordination and power manifested in ECC contractions are the main attributes of elite skiers, especially in SL. Having in mind that parts of the brain spheres activated during ECC contraction are different from those active during the movements involving CON contraction, from the control aspect, it is necessary to practice the tasks involving ECC contractions un- der specific conditions and exercises that mime the movements in the snow (Fang, Siemionow, Sahgal, Xiong, \& Yue, 2004).

\section{PRACTICAL APPLICATIONS OF ECCENTRIC TRAINING IN SKIING}

Alpine skiing represents a complex integration of various physiological systems neither of which may be more important than the other in their total capacity. When developing and assesing the success factors, the specificities of skiing kinematics and dynamics must be taken into account (Ropret, 2015). One of the specific features of skiing is a considerable volume of ECC regime of leg muscle work where the movement mechanics significantly differs from other sports.

Intense muscular strains that require a high level of maximum muscle power, strength endurance lasting for 1-2 min, high level of coordination of the movements (balance and precise leg movements) on unstable surface, under specific conditions of increased altitudes (rarefied air, cold) are undisputable. The loads of 2-4.5 G require training with additional load for the development of maximumn power and particularly in ECC contraction regime. A greater number of repetitions of the movements and duration of the activity (30-70 turns during 1-2 min) require the development of great endurance.

Effects of ECC training have manifold significance for skiers' training: increase in maximum power and strength, optimum ratio between strength and muscle length, intra and intermuscular coordination enhancement, injury prevention, explosive strength increase without application of intense jumping exercises, more efficient metabolic work, development of great endurance, larger volume of work, work involving the movements similar to skiing, improvement of the relations between agonist and antagonist muscle power.

The ability to absorb kinetic energy and good neuro-muscular movement control in ECC regime must be practised in specific conditions or conditions as similar to skiing as possible. Preference is given to the exercises using ergometers compared to traditional plyometric exercises for several reasons: skiing movements are slower, amplitudes of the knee joint movements are higher, power generation lasts longer and coupling phase is not that important in relation to plyometric exercises. In addition, stretching and fold- 
ing movements in skiing are not ultimately aimed at high takeoff, but at absorption and dosage of the load caused by gravitation and inertion, along with control of fine leg movements at such heavy loads. Unlike the exercises using ergometers, plyometric exercises are performed in motion of low amplitude with small changes in joint angles, which is not characteristic of skiing. Because of this, the exercises in ECC regime using ergometers have an advantage over jumping exercises.

Using metabolically favorable ECC method provides the opportunity to apply a "high volume-low intensity" method, which is particularly important for the development of an endurance component in leg strength in skiers.

\section{REFERENCES}

1. Baroni, B.M., Rodrigues, R., Franke, R.A., Geremia, J.M., Rassier, D.E., \& Vaz, M.A. (2013). Time course of neuromuscular adaptations to knee extensor eccentric training. International Journal of Sports Medicine, 34, 904-911.

2. Berg, H.E., Eiken, O., \& Tesch, P.A. (1995). Involvement of eccentric muscle actions in giant slalom racing. Medicine \& Science in Sports Exercise, 27, 1666-1670.

3. Berg, E.H., \& Eiken, O. (1999). Muscle control in elite alpine skiing. Medicine \& Science in Sports Exercise, 31(7), 1065-1067.

4. Bigland-Ritchie, B., \& Woods, J.J. (1976). Integrated electromyogram and oxygen uptake during positive and negative work. Journal of Physiology, 260, 267-277.

5. Cook, C.J, Beaven, C.M., \& Kilduff, L.P. (2013). Three weeks of eccentric training combined with overspeed exercises enhances power and running speed performance gains in trained athletes. Journal of Strength and Conditioning Research, 27, 1280-1286.

6. Elmer, S., Hahn, S., McAllister, P., Leong, C., \& Martin, J. (2012). Improvements in multi-joint leg function following chronic eccentric exercise. Scandinavian Journal of Medicine and Science in Sports, 22, 653-661.

7. Elmer, S.J., \& Martin, J.C. (2013). Construction
The studies so far have included a variety of training and measuring protocols. The experiments lasted 5-10 weeks, with 2-3 training sessions per week in a form of continous duration of between 15 and 30 minutes or 3-4 sets with 7-10 repetitions with a oneday break between workouts. The loads were gradually increased, starting from the initial load of $130 \mathrm{~W}$ in untrained skiers to $1200 \mathrm{~W}$ in the elite ones. Despite the specified differences in methodology, all the studies have indicated a positive effect of ECC training on the development of skiers' performances regarding power, strength and endurance enhancement. It is necessary to conduct further research related to determining the optimum volume, intenisty, velocity and protocol of this type of training with a special focus on the specificities of alpine skiing.

of an isokinetic eccentric cycle ergometer for research and training. Journal of Applied Biomechanics, 29, 490-495.

8. Fang, Y., Siemionow, V., Sahgal, V., Xiong, F., \& Yue, G.H. (2004). Distinct brain activation patterns for human maximal voluntary eccentric and concentric muscle actions. Brain Research, 1023, 200-212.

9. Folland, J.P., \& Williams, A.G. (2007). The adaptations to strength training: morphological and neurological contributions to increased strength. Sports Medicine, 37, 145-168.

10. Friedmann-Bette, B., Bauer, T., Kinscherf, R., Vorwald, S., Klute, K., Bischoff, D., Muller, H., Weber, M.A., Metz, J., Kauczor, H.U., Bartsch, P., \& Billeter, R. (2010). Effects of strength training with eccentric overload on muscle adaptation in male athletes. European Journal of Applied Physiology, 108, 821-836.

11. Gross, M., Luthy, F., Kroell, J., Muller, E., Hoppeler, H., \& Vogt, M. (2010). Effects of eccentric cycle ergometry in alpine skiers. International Journal of Sports Medicine, 31, 572-576.

12. Guilhem, G., Cornu, C., \& Guevel, A. (2010). Neuromuscular and muscle-tendon system adaptations to isotonic and isokinetic eccentric exercise. Annals of Physical Rehabilitation Medicine, 53, 319-341. 
13. Guilhem, G., Cornu, C., Maffiuletti, N.A., \& Guevel, A. (2013). Neuromuscular adaptations to isoload versus isokinetic eccentric resistance training. Medicine \& Science in Sports Exercise, $45,326-335$.

14. Hoopler, H. (2014). Eccentric Exercise: Physiology and Application in Sport and Rehabilitation. London: Routledge.

15. Isner-Horobeti, M.E., Dufour, S.P., Vautravers, P., Geny, B., Coudeyre, E., \& Richard, R. (2013). Eccentric exercise training: modalities, Applications and perspectives. Sport Medicine, 43, 483512

16. LaStayo, P.C., Pierotti, D.J., Pifer, J., Hoppeler, H., \& Lindstedt, S.L. (2000). Eccentric ergometry: increases in locomotor muscle size and strength at low training intensities. American journal of physiology. Regulatory, integrative and comparative physiology, 278, R1282-R1288.

17. Lindstedt, S.L., Reich, T.E., Keim, P., \& LaStayo, P.C. (2002). Do muscles function as adaptable locomotor springs? Journal of Experimental Biolo$g y, 205,2211-2216$.

18. Linthorne, P.N. (2001). Analysis of standing vertical jumps using a force platform. American Journal of Physics, 69(11), 1198-1204.

19. Mjolsnes, R., Arnason, A., Osthagen, T., Raastad, T., \& Bahr, R. (2004). A 10-week randomized trial comparing eccentric vs. concentric hamstring strength training in well-trained soccer players. Scandinavian Journal of Medicine and Sciences inSports, 14, 311-317.

20. Patterson, C., Raschner, C., \& Platzer, H.P. (2009). Pover variables and bilateral force differences during unloaded and loaded squat jumps in hige performance alpine ski races. Journal of Strength and Conditioning Research, 23(3), 779-87
21. Roig, M., O’Brien, K., Kirk, G., Murray, R., McKinnon, P., Shadgan, B., \& Reid, W.D. (2009). The effects of eccentric versus concentric resistance training on muscle strength and mass in healthy adults: a systematic review with meta-analysis. British Journal of Sports Medicine, 43, 556-568.

22. Ropret, R. (2015). Limiting factors for success in alpine skiing. Facta universitatis, Series: Physical Education and Sport, 13(2), 167-176.

23. Sheppard, J.M., Hobson, S., Barker, M., Taylor, K., Chapman, D., McGuigan, M., \& Newton, R. (2008). The effect of training with ccentuated eccentric load counter-movement jumps on strength and power characteristics of high-performance volleyball players. The International Journal of Sports Science \& Coaching, 3, 355-363.

24. Vogt, M., (2011). Eccentric exercise training in elite skiing. In: Proc 16th ECSS Congress. Liverpool, UK.

25. Vogt, M., \& Hoppeler, H. (2012). Competitive alpine skiing: combining strength and endurance training. Molecular bases and applications. In Mueller E, Lindinger S, Stoeggl T. (eds.), Science and Skiing V,(pp. 23-31). Aachen: Meyer and Meyer Sport.

26. Vogt, M., \& Hoppeler, H. (2009). Eccentrics exercise in Alpine skiing. In In Mueller E, Lindinger S, Stoeggl T. (eds.), Science and Skiing IV,(pp. 33-42). Aachen: Meyer and Meyer Sport.

27. Vogt, M., Dapp, C., Blatter, J., Weisskopf, J., Suter, G., \& Hoppeler, H. (2003). Training zur Optimierung der Dosierung exzentrischer Muskelaktivität. Schweizer Z Sportmed Sporttraum, 188-191.

28. Wilson, G., Elliot, B., \& Wood, G. (1990) The use of elastic energy in sport. Sports Coach 13(3), 8-10. 


\title{
ROLLE DES EXZENTRISCHEN ARBEITSREGIMES DER BEINMUSKELN IN DER ALPINEN SKIFAHRT
}

\begin{abstract}
Zusammenfassung
Die alpine Skifahrt charakterisiert eine große Anzahl von Beinbewegungen mit Muskelkontraktionen in einem exzentrischen Arbeitsregime. Die Rolle dieser Bewegungen ist die Absorption von Gravitations- und Inertionskraft, präzise Führung der Skier und die Erhaltung des Gleichgewichts. Bisherige Untersuchungen haben Umfang, Dauer und Intensität der exzentrischen Kontraktionen festgelegt sowie die Grundeigenschaften der Bewegungsamplituden und -geschwindigkeiten. Auf Grund früherer Erkenntnisse wurden Experimente mit einem exzentrischen Training auf einem Fahrradergometer durchgeführt, durch die ein positiver Einfluss dieses Trainings auf die Steigerung der Maximalkraft, der Ausdauerkraft, der Koordinierung, der Verletzungsprävention, der metabolischen Leistungseffizienz, der effizienteren Leistung bei größerer Muskellänge und auf die Rolle in der Nachahmung der Bewegungen der Skifahrer bestätigt wurde. Diese Arbeit stellt eine kurze Übersicht der bisherigen Untersuchungen aus dem Bereich der Kinematik, der Dynamik des Skifahrens und der Rolle des exzentrischen Trainings in der Entwicklung der Fähigkeiten der Skifahrer dar.
\end{abstract}

Schlüsselwörter: TRAINING / KRAFT / EXZENTRISCHE KONTRAKTION / PRÜFUNG

Received: 27.09.2016.

Accepted: 10.04.2017. 


\title{
УЛОГА ЕКСЦЕНТРИЧНОГ РЕЖИМА РАДА МИШИЋА НОГУ У АЛПСКОМ СКИЈАҢУ
}

\author{
Роберт Ропрет \\ Универзитет у Београду, Факултет спорта и физичког васпитања
}

\begin{abstract}
Сажетак
Алпско скијање карактерише велики број покрета ногу са мишићним контракцијама у ексцентричном режиму рада. Улога тих покрета је апсорпција гравитационе и инерционих сила, прецизно управљање скијама и одржавање равнотеже. Досадашња истраживања су утврдила обим, трајање и интензите ексцентричних контракција као и основне карактеристике амплитуда и брзина покрета. На основу претходних сазнања вршени су експерименти са ексцентричним тренингом на бицикл-ергометру којима је потврђен позитиван утицај овог тренинга на повећање максималне силе, снаге, издржљивости, координације, превенцију повређивања, метаболичку ефикасност рада, ефикаснији рад при већој дужини мишића и улогу у имитацији покрета скијаша. Рад представља кратак преглед досадашњих истраживања из области кинематике, динамике скијања и улоге ексцентричног тренинга на развој способности скијаша.
\end{abstract}

Кључне речи: ТРЕНИНГ / СНАГА / ЕКСЦЕНТРИЧНА КОНТРАКЦИЈА / ТЕСТИРАҢЕ

\section{УВОД}

Алпско скијање, рекреативно или такмичарско, представља кретање на скијама низ падину, под утицајем гравитације, при чему скијаш врши покрете у циљу промене правца и контроле брзине. Покрети се врше у условима концентричних $(\mathrm{KOH})$, изометријских (ИЗО) и ексцентричних (ЕКС) контракција мишића. 3бог дејства гравитације и инерције значајан део покрета се одвија у условима ЕКС режима рада мишића опружача ногу (Berg \& Eiken, 1999). Способност контролисања силе мишића опружача зглоба колена у ЕКС режиму рада може бити кључни лимитирајући фактор у успешности испољавања правилне технике у скијању. Сазнања о карактеристикама ЕКС режима рада, динамичким и кинетичким карактеристикама алпског скијања могу значајно допринети у планирању тренинга и побољшању способности такмичара. Циљ рада је да се, на основу сазнања о улози ексцентричног рада мишића екстензора током скијања утврде адекватне методе и средства за развој снаге ногу код скија- ша. Истраживање је обухватило преглед база радова PubMed, Medline и Google претраживача. Радови су изабрани комбиновањем кључних речи: алпско скијање, тренинг снаге, ексцентрична контракција. Прегледом су одабрани радови у складу са темом, објављени у периоду од 1995. до јула 2016. године.

\section{КАРАКТЕРИСТИКЕ ЕКСЦЕНТРИЧ- НОГ РЕЖИМА РАДА МИШИЋА}

Ексцентрична контракција подразумева мишићни рад у условима када спољашње оптерећење превазилази силу мишића, због чега долази до издуживања мишићно-тетивног система и мишић ради у такозваном „попуштајућем режиму“ (Lindstedt, Reich, Keim, \& LaStayo, 2002). ЕКС контракција има улогу у смањењу, прекидању или апсорпцији енергије кретања. Апсорбована енергија може бити ослобођена у виду топлоте или као еластична енергија. У првом случају, када су 
покрети спорији, ефекат рада мишића је апсорпција оптерећења, као на пример у скијању, трчању низбрдо или саскоцима са висине. У другом случају, током брзих и цикличних покрета (спринт, скокови), апсорбована енергија се ослобађа и омогућава ефикаснију наредну контракцију у тзв.

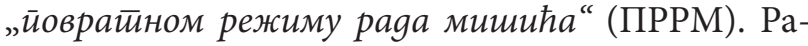
злози за овакве ефекте ЕКС контракције нису у потпуности објашњени. Поједини аутори сматрају да се апсорбована енергија на крају ЕКС контракције ослобађа као еластична енергија у тетивама, у брзом покрету који следи (као истегнута еластична опруга). Да би се повратни ефекат искористио потребно је да време између краја ЕКС и почетка КОН контракције („време сйајаға“) буде кратко јер ће се у супротном еластична енергија претворити у топлотну. Првобитно се сматрало да то време не може бити дуже од 0.15 мс да би Вилсон, Елиот и Вуд (Wilson, Elliot, \& Wood, 1990) закључили да се ефекти мањег интензитета могу искористити у периоду до 4 сек. Други аутори сматрају да је појачан ефекат КОН контракције последица дејства рефлекса на истезање. Трећи, сматрају да ЕКС контракција омогућава мишићу да успостави своју (пре)активацију на вишем нивоу и да КОН контракцију започне са већим активацијским потенцијалом (Linthorne, 2001).

\section{Ексцентрични тренинг и адаптациони процеси}

У поређењу са покретима у КОН режиму, рад у ЕКС режиму је енергетски и метаболички ефикаснији, и до 50\% (Isner-Horobeti, Dufour, Vautravers, Geny, Coudeyre, \& Richard, 2013). Тиме се пружа могућност да се ЕКС тренингом значајно више оптерете мишићи, уз ниже метаболичке захтеве „више ефекта уз мање улагање“ (LaStayo, Pierotti, Pifer, Hoppeler, \& Lindstedt, 2000). Током ЕКС педалирања на бицикл-ергометру потрошња $\mathrm{O}_{2}$ може износити 1/6-1/7 потрошње у односу на педалирање у КОН режиму (Biglan-Ritchie \& Woods, 1976). Вогт (Vogt, 2011) је у експерименту са ЕКС педалирањем на бицикл-ергометру остварио укупан обим рада од 240 тона по тренингу, што је готово немогуће постићи педалирањем у КОН режиму. ЛаСтајо и сарадници (LaStayo, et all., 2000) су у експерименту педалирања на бицикл-ергометру, при интензитету рада од 65\% $\mathrm{VO}_{2} \max$, забележили рад са четири пута већим оптерећењем у ЕКС режиму (489 W) у односу на групу која је радила у КОН режиму $(128 \mathrm{~W})$.

Адаптациони процеси под утицајем ЕКС тренинга се испољавају променама у нервном и мишићном систему. Повећава се мишићна маса услед хипертрофије мишићних влакана брзог типа - Іа и IIx (Folland \& Williams, 2007; Friedmann-Bette et all, 2010; Guilhem, Cornu, \& Guevel, 2010; Baroni, Rodrigues, Franke, Geremia, Rassier, \& Vaz, 2013). Адаптационе промене након ЕКС тренинга доводе до повећања брзине контракције, дужине мишићног вретена, повећање капацитета за ефикасније коришћење акумулиране еластичне енергије у мишићно-тетивном систему (Lindstedt, at all., 2002), укупне ефикасности рада и боље превенције од повређивања.

Замор је важан фактор у испољавању еластичних својстава мишића јер умањује ефекат мишићне активности. Применом различитих модела тренинга утврђено је да је потребно више од 24 сата за опоравак мишића након напорног ЕКС тренинга као и да је, због великог обима рада, могуће примењивати највише 2 до 3 ЕКС тренинга недељно (LaStayo, et all., 2000; Vogt \& Hoppeler, 2009).

\section{Утицај ексцентричног тренинга на развој снаге}

Предности ЕКС над КОН методом тренинга доказиване су у неколико експеримената на нетренираним испитаницима. Неколико експеримената у трајању од 7-10 недеља, показало је позитиван утицај на повећање максималне изометријске силе од $36 \%$ (LaStayo, et all., 2000) и снаге у серијама скокова у висину за 7\% (Elmer, Hahn, McAllister, Leong, \& Martin, 2012) као и да метод „велики обим-низак интензитет“" вежठи у ЕКС режиму показује боље резултате у односу на метод „велики интензитет-низак обим“. У два експеримента сличног трајања (број тренинга х број серија х број понављања), Гуилхем и сар. (Guilhem, et all., 2010; Guilhem, Cornu, Maffiuletti, \& Guevel 2013) применили су два метода у вежбама са ЕКС режимом рада мишића: изотонични и изокинетички. На крају је утврђено да су учесници изокинетичког експеримента просечно обавили рад двоструко већег обима, али да је већи ефекат на повећање снаге остварен изотоничним методом (2.4\%).

Мали број истраживања, на тренираним спортистима, такође је указао на позитиван утицај ЕКС тренинга. Различити експерименти, у којима су две групе примењивале КОН и ЕКС режим 
рада, трајали су 3-10 недеља, 3-4 тренинга недељно. Упркос различитој методологији експеримента, групе са ЕКС режимом су показале боље резултате од група са традиционалним КОН тренингом у побољшању: висине скокова (8\%), фреквенције покрета за 11\% (Lindstedt, et all., 2002); максималне изометријске силе мишића задње

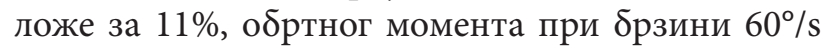
за $0.4 \%$ по тренингу (Mjolsnes, Arnason, Osthagen, Raastad, \& Bahrl, 2004); висини скокова за 11\% (Sheppard, et all., 2008); проценту IIа типа влакана (Friedmann et all, 2010); у снази и висини скокова за 5\% (Cook, Beaven, \& Kilduff, 2013).

\section{Утицај ексцентичног тренинга на коорди- нацију}

Између КОН и ЕКС контракције мишића постоје разлике у процесу програмирања покрета на нивоу Централног невног система (ЦНС). Истраживање Гуилхема и сарадника (Guilhem, et all., 2010) показало је већи ниво ЕЕГ активности кортекса приликом ЕКС контракције у односу на КОН. На мишићном нивоу, за сличан интензитет силе забележен је нижи ниво ЕМГ активности током ЕКС у односу на КОН контракцију (Biglan-Ritchie \& Woods, 1976). Аутори претпостављају, да се при ЕКС контракцији активира мањи број моторних јединица, у односу на КОН контракцију истог интензитета. У том случају долази до повећања механичког оптерећења по активираној моторној јединици. 3бог тога је теже контролисати и координисати покрете при ЕКС контракцији.

\section{Варијанте ексцентричног тренинга}

Према скоријим истраживањима (Roig, et all., 2009; Vogt \& Hoppeler, 2009; Guilhem, et all., 2010; Elmer, et all., 2012; Isner, et all., 2013; Elmer \& Martin, 2013) најчешће се примењују два модела тренинга са ЕКС режимом:

1. "Висок интензитет-мали обим" је тренинг са великим оптерећењима (око 1 понављајућег максимума (1RM), и малим бројем серија, углавном са „чистом ексцентријом“ или „мешовитом ексцентрично-концентричном контракцијом“ при чему су вежбе „изотоничне“ или „изокинетичке“. Углавном се примењује на тренанжерима са додатним оптерећењем.

2. „Низак интензитет-велики обим“ је тренинг са већим бројем понављања и субмак- сималним оптерећењем. Најчешће се примењује на ергометрима за ексцентрични режим рада.

ЕКС тренингом са супрамаксималним и максималним оптерећењем ( $\geq 1 \mathrm{PM})$ повећава се максимална сила и мишићна маса. Субмаксималним оптерећењима ( $\leq 1 \mathrm{PM})$ остварује се побољшање у снази и мишићнот тонуси. Тренинг за развој ових способности обухвата вежбе са надоптерећењем (>1 РМ), плиометријске вежбе, вежठе сопственим телом (нпр: „Нордијска вежठа за задњу ложу“) или вежбе на ергометрима (тренанжери са инерцијалним оптерећењем и бицикл-ергометри).

\section{КАРАКТЕРИСТИКЕ МИШИТНЕ АКТИВНОСТИ НОГУ КОД СКИЈАША}

Насупрот утиску да је алпско скијање динамична активности са пуно експлозивних покрета, угаоне брзине у зглобу колена и кука показују да скијање није спорт који карактерише максимална брзина покрета (Berg, Eiken, \& Tesch, 1995; Patterson, Raschner, \& Platzer, 2009). Просечне угаоне брзине у зглобу колена се крећу у распону $20-40 \%$ s, а максималне забележене, од 69\%/s, су далеко од угаоних ठрзина у зглобу колена спринтера и скакача $(1000 \%$ s) или бициклиста $(200-400 \%$ s) (Berg \& Eiken 1999). Брзина генерисања силе је спорија и максималне вредности се достижу касније (Patterson, et all., 2009). Оно што скијање чини различитим од већине других спортова је што у већем делу заокрета, због кретања низ падину, доминирају ЕКС контракције. Континуирано кретање тела низ падину повећаном брзином (30-100 km/h) генерише кинетичку енергију, а тиме и велико оптерећење за опружаче у зглобу колена. Оптерећења која скијаши савладавају током заокрета износе 2-4.5 G (Hoppeler, 2014), односно 58-112\% максималне вољне изометријске контракције (МВК). Трајање фазе ЕКС контракције у слалому (СЛ) износи $84,5 \%$, а у велеслалому (BC) $88.2 \%$ од укупног трајања заокрета, што говори о великом обиму ЕКС режима рада мишића у циљу супротстављања инерционим силама и одржавања положаја (Berg, Eiken, \& Tesch, 1995).

У погледу улоге одређеног типа влакана, истраживање Вогта и Хопелера (Vogt \& Hoppeler, 
2012) указује на малу, али значајну доминацију спорих (I) у односу на брза влакна (II) у узорку елитних скијаша, као и да постоји корелација између успешности у такмичарским резултатима (ФИС бодови) и типа влакана спорог трзаја (I). Претпоставка је да брзина и интензитет целокупног циклуса ЕКС и КОН контракције зависи од типа мишићних влакана и њихове дужине.

Амплитуде покрета, углови у зглобу колена, трајање, брзина и фреквенција покрета као и карактеристике мишићне активности указују да се покрети у скијању могу класификовати између спорог ПРРМ и функције апсорпције удара. Наведене карактеристике су изазов за планирање и примену ЕКС вежби у тренингу снаге алпских скијаша.

\section{УТИЦАЈ ВЕЖБИ СА ЕКСЦЕНТРИЧНИМ РЕЖИМОМ МИШИЋНОG РАДА НА СПОСОБНОСТИ СКИЈАША}

У складу са претходним резултатима, вршена су одређена истраживања о утицају ЕКС тренинга на развој снаге, издржљивости и координације скијаша. Вогт (Vogt, 2011) је у експерименту са скијашима применио тренинг на ексцентричном бицикл-ергометру у трајању од 6 недеља. Контролна група је имала класичан КОН тренинг 3 пута недељно у трајању од 60 мин, а експериментална $40 \mathrm{KOH}+20$ ЕКС минута тренинга на бицикл-ергометру. Оठе групе су забележиле повећање од $10 \%$ у ИЗО сили, док је само експериментална забележила повећање од $7.9 \%$ у тесту скока у вис из места. Грос, Лути, Кроел, Милер, Хопелер и Вогт (Gross, Luthy, Kroell, Muller, Hoppeler, \& Vogt, 2010) и Вогт и Хопелер (Vogt \& Hoppeler, 2012) су спровели експерименте са врхунским скијашима током 5 недеља. Поред класичног тренинга снаге (без скокова), скијаши су примењивали 1-2 пута недељно, серију од 20 мин на ЕКС бицикл-ергометру. Оптерећење се постепено повећавало и на крају је износило 140\% почетног (од 404 до 965 $\mathrm{W})$. Забележено је повећање у изометријској сили (12\%), мишићној маси ногу (1.9\%), максималној снази код скокова у вис из места $(8.8 \%)$, из чучња $(9.2 \%)$, као и силе у ЕКС контракцији (100\% сопствене тежине). Упркос интензивном, али постепеном повећању оптерећења није забележена појава „упале мишића“. Наведена истраживања указују да примена ЕКС тренинга утиче на побољшање максималне силе као и снаге, без примене скокова. Истраживања Вогт и сарадника, (Vogt, Dapp, Blatter, Weisskopf, Suter, \& Hoppeler, 2003) на ЕКС ергометру, показала су да успешнији скијаши показују бољу координацију покрета (однос оптерећења и испољене снаге). Повезаност резултата је забележена код скијаша у дисциплинама СЛ и ВС али не и у ДХ (спуст). Резултат је разумљив када се има у виду динамика покрета (дужи и спорији покрети у ДХ) и протокол примењеног теста (већа фреквенција покрета). Резултати ЕКС тренинга указују да су добра координација и сила испољене у ЕКС контракцијама основни атрибути врхунских скијаша, нарочито у СЛ. Имајући у виду да су током ЕКС контракције активни различити делови можданих сфера у односу на покрете са КОН контракцијом, са управљачког аспекта, потребно је да се задаци са ЕКС контракцијама увежбавају у специфичним ситуацијама и вежठама које имитирају покрете на снегу (Fang, Siemionow, Sahgal, Xiong, \& Yue, 2004).

\section{ПРАКТИЧНА ПРИМЕНА ЕКСЦЕНТРИЧНОG ТРЕНИНGА У СКИЈАњУ}

Алпско скијање представља сложену интеграцију различитих физиолошких система, од којих ниједан не може бити важнији од другог у укупној способности. У развоју и процени фактора успешности мора се водити рачуна о специфичностима кинематике и динамике скијања (Ропрет, 2015). Једна од специфичности скијања је значајан обим ЕКС режима рада ногу по чему се механика покрета значајно разликује од других спортова.

Неспорна су интензивна мишићна напрезања која захтевају висок ниво максималне силе мишића, издржљивост у снази у трајању од 1-2 мин, висок ниво координације покрета (равнотежа и прецизни покрети ногу) на нестабилној подлози, у специфичним условима увећане надморске висине (разрећен ваздух, хладноћа). Оптерећења од 2-4.5 G захтевају тренинг са додатним оптерећењем за развој максималне силе а нарочито у режиму ЕКС контракције. Већи број понављања покрета и трајање активности (30-70 заокрета током 1-2 мин) захтевају развој снажне издржљивости. 
Ефекти ЕКС тренинга су вишеструко значајни за тренинг скијаша: повећање максималне силе и снаге; оптимални однос снаге и дужине мишића; побољшање унутар и међумишићне координације; превенција од повређивања; повећање експлозивне снаге без примене интензивних вежби скокова; метаболички економичнији рад; развој снажне издржљивости; већи обим рада; рад у покретима сличним као у скијању; побољшање односа силе агониста и антагониста.

Способност апсорпције кинетичке енергије и добра нервно-мишићна контрола покрета у ЕКС режиму морају да се вежбају у специфичним или условима што сличнијим током скијања. Предност имају вежбе на ергометрима у односу на класичне плиометријске вежбе из неколико разлога: покрети у скијању су спорији, амплитуде покрета у зглобу колена су веће, генерисање силе траје дуже и фаза спајања нема толики значај у односу на плиометријске вежбе. Такође, покрети опружања и прегибања у скијању немају као крајњи циљ снажан одраз већ апсопцију и дозирање оптерећења изазваног дејством гравитације и инерције, уз контролу финих покрета ногу при овако великим оптерећењима. За разлику од вежби на ергометрима, плиометријске вежбе се врше у по-

\section{ЛИТЕРАТУРА}

1. Baroni, B.M., Rodrigues, R., Franke, R.A., Geremia, J.M., Rassier, D.E., \& Vaz, M.A. (2013). Time course of neuromuscular adaptations to knee extensor eccentric training. International Journal of Sports Medicine, 34, 904-911.

2. Berg, H.E., Eiken, O., \& Tesch, P.A. (1995). Involvement of eccentric muscle actions in giant slalom racing. Medicine \& Science in Sports Exercise, 27, 1666-1670.

3. Berg, E.H., \& Eiken, O. (1999). Muscle control in elite alpine skiing. Medicine \& Science in Sports Exercise, 31(7), 1065-1067.

4. Bigland-Ritchie, B., \& Woods, J.J. (1976). Integrated electromyogram and oxygen uptake during positive and negative work. Journal of Physiology, 260, 267-277.

5. Vogt, M. (2011). Eccentric exercise training in elite skiing. In: Proc 16th ECSS Congress. Liverpool, UK. кретима мале амплитуде, при малим променама у угловима зглобова, а што није карактеристично за скијање. Због наведеног, вежбе у ЕКС режиму на ергометру имају предност над вежбама са скоковима.

Коришћење метаболички повољнијег ЕКС метода рада даје могућност примене метода „великог обима-малог интензитета“"што је од посебног значаја за развој компоненте издржљивости у снази ногу код скијаша.

Досадашња истраживања су обухватила различите протоколе тренирања и мерења. Експерименти су трајали 5-10 недеља, са 2-3 тренинга недељно у форми континуираног трајања између 15 и 30 минута или 3-4 серије са 7-10 понављања, са даном паузе између тренинга. Оптерећења су се постепено повећавала, од почетних $130 \mathrm{~W}$ код нетренираних до $1200 \mathrm{~W}$ код врхунских скијаша. Упркос наведеним разликама у методологији, сва истраживања су указала на позитивну улогу ЕКС тренинга у развоју способности скијаша у погледу повећања силе, снаге и издржљивости. Неопходна су даља истраживања у вези са одређивањем оптималног обима, интензитета, брзине и протокола ове врсте тренинга са посебним освртом на специфичности алпског скијања.

6. Vogt, M., \& Hoppeler, H. (2012). Competitive alpine skiing: combining strength and endurance training. Molecular bases and applications. In Mueller E, Lindinger S, Stoeggl T. (eds.), Science and Skiing $V$,(pp. 23-31). Aachen: Meyer and Meyer Sport.

7. Vogt, M., \& Hoppeler, H. (2009). Eccentrics exercise in Alpine skiing. In In Mueller E, Lindinger S, Stoeggl T. (eds.), Science and Skiing IV,(pp. 33-42). Aachen: Meyer and Meyer Sport.

8. Vogt, M., Dapp, C., Blatter, J., Weisskopf, J., Suter, G., \& Hoppeler, H. (2003). Training zur Optimierung der Dosierung exzentrischer Muskelaktivität. Schweizer Z Sportmed Sporttraum, 188-191.

9. Wilson, G., Elliot, B., \& Wood, G. (1990) The use of elastic energy in sport. Sports Coach 13(3), 8-10.

10. Gross, M., Luthy, F., Kroell, J., Muller, E., Hoppeler, H., \& Vogt, M. (2010). Effects of eccentric cycle ergometry in alpine skiers. International Journal of Sports Medicine, 31, 572-576. 
11. Guilhem, G., Cornu, C., \& Guevel, A. (2010). Neuromuscular and muscle-tendon system adaptations to isotonic and isokinetic eccentric exercise. Annals of Physical Rehabilitation Medicine, 53, 319-341.

12. Guilhem, G., Cornu, C., Maffiuletti, N.A., \& Guevel, A. (2013). Neuromuscular adaptations to isoload versus isokinetic eccentric resistance training. Medicine \& Science in Sports Exercise, $45,326-335$.

13. Elmer, S., Hahn, S., McAllister, P., Leong, C., \& Martin, J. (2012). Improvements in multi-joint leg function following chronic eccentric exercise. Scandinavian Journal of Medicine and Science in Sports, 22, 653-661.

14. Elmer, S.J., \& Martin, J.C. (2013). Construction of an isokinetic eccentric cycle ergometer for research and training. Journal of Applied Biomechanics, 29, 490-495.

15. Isner-Horobeti, M.E., Dufour, S.P., Vautravers, P., Geny, B., Coudeyre, E., \& Richard, R. (2013). Eccentric exercise training: modalities, Applications and perspectives. Sport Medicine, 43, 483-512

16. LaStayo, P.C., Pierotti, D.J., Pifer, J., Hoppeler, H., \& Lindstedt, S.L. (2000). Eccentric ergometry: increases in locomotor muscle size and strength at low training intensities. American journal of physiology. Regulatory, integrative and comparative physiology, 278, R1282-R1288.

17. Lindstedt, S.L., Reich, T.E., Keim, P., \& LaStayo, P.C. (2002). Do muscles function as adaptable locomotor springs? Journal of Experimental Biolo$g y, 205,2211-2216$.

18. Linthorne, P.N. (2001). Analysis of standing vertical jumps using a force platform. American Journal of Physics, 69(11), 1198-1204.

19. Mjolsnes, R., Arnason, A., Osthagen, T., Raastad, T., \& Bahr, R. (2004). A 10-week randomized trial comparing eccentric vs. concentric hamstring strength training in well-trained soccer players. Scandinavian Journal of Medicine and Sciences inSports, 14, 311-317.

20. Patterson, C., Raschner, C., \& Platzer, H.P. (2009). Pover variables and bilateral force differences during unloaded and loaded squat jumps in hige performance alpine ski races. Journal of Strength and Conditioning Research, 23(3), 779-87

21. Roig, M., O'Brien, K., Kirk, G., Murray, R., McKinnon, P., Shadgan, B., \& Reid, W.D. (2009). The effects of eccentric versus concentric resistance training on muscle strength and mass in healthy adults: a systematic review with meta-analysis. British Journal of Sports Medicine, 43, 556-568.

22. Ropret, R. (2015). Limiting factors for success in alpine skiing. Facta universitatis, Series: Physical Education and Sport, 13(2), 167-176.

23. Sheppard, J.M., Hobson, S., Barker, M., Taylor, K., Chapman, D., McGuigan, M., \& Newton, R. (2008). The effect of training with ccentuated eccentric load counter-movement jumps on strength and power characteristics of high-performance volleyball players. The International Journal of Sports Science \& Coaching, 3, 355-363.

24. Fang, Y., Siemionow, V., Sahgal, V., Xiong, F., \& Yue, G.H. (2004). Distinct brain activation patterns for human maximal voluntary eccentric and concentric muscle actions. Brain Research, 1023, 200-212.

25. Folland, J.P., \& Williams, A.G. (2007). The adaptations to strength training: morphological and neurological contributions to increased strength. Sports Medicine, 37, 145-168.

26. Friedmann-Bette, B., Bauer, T., Kinscherf, R., Vorwald, S., Klute, K., Bischoff, D., Muller, H., Weber, M.A., Metz, J., Kauczor, H.U., Bartsch, P., \& Billeter, R. (2010). Effects of strength training with eccentric overload on muscle adaptation in male athletes. European Journal of Applied Physiology, 108, 821-836.

27. Hoopler, H. (2014). Eccentric Exercise: Physiology and Application in Sport and Rehabilitation. London: Routledge.

28. Cook, C.J, Beaven, C.M., \& Kilduff, L.P. (2013). Three weeks of eccentric training combined with overspeed exercises enhances power and running speed performance gains in trained athletes. Journal of Strength and Conditioning Research, 27, 1280-1286. 


\section{ROLLE DES EXZENTRISCHEN ARBEITSREGIMES DER BEINMUSKELN IN DER ALPINEN SKIFAHRT}

\section{Zusammenfassung}

Die alpine Skifahrt charakterisiert eine große Anzahl von Beinbewegungen mit Muskelkontraktionen in einem exzentrischen Arbeitsregime. Die Rolle dieser Bewegungen ist die Absorption von Gravitations- und Inertionskraft, präzise Führung der Skier und die Erhaltung des Gleichgewichts. Bisherige Untersuchungen haben Umfang, Dauer und Intensität der exzentrischen Kontraktionen festgelegt sowie die Grundeigenschaften der Bewegungsamplituden und -geschwindigkeiten. Auf Grund früherer Erkenntnisse wurden Experimente mit einem exzentrischen Training auf einem Fahrradergometer durchgeführt, durch die ein positiver Einfluss dieses Trainings auf die Steigerung der Maximalkraft, der Ausdauerkraft, der Koordinierung, der Verletzungsprävention, der metabolischen Leistungseffizienz, der effizienteren Leistung bei größerer Muskellänge und auf die Rolle in der Nachahmung der Bewegungen der Skifahrer bestätigt wurde. Diese Arbeit stellt eine kurze Übersicht der bisherigen Untersuchungen aus dem Bereich der Kinematik, der Dynamik des Skifahrens und der Rolle des exzentrischen Trainings in der Entwicklung der Fähigkeiten der Skifahrer dar. Schlüsselwörter: TRAINING / KRAFT / EXZENTRISCHE KONTRAKTION / PRÜFUNG

Примљен: 27.09.2016.

Прихваћен: 10.04.2017. 